\title{
Symbolic Sounds in Ulysses ${ }^{*}$
}

\author{
Xianyou $\mathrm{Wu}$ \\ School of Foreign Languages, Chongqing Normal University, Chongqing, China \\ Yi Zheng \\ School of Foreign Languages, Chongqing Normal University, Chongqing, China
}

\begin{abstract}
Reading Ulysses, all kinds of sounds impinge on our ears from all sides. They may be human or nonhuman, loud or low, soft or rough, funny or ridiculous. This paper will explore the different symbolic or metaphorical implications of two distinctive sounds: the church bells and the jingling sound. It seems that few Joycean scholars have attended to Joyce's manipulating of sounds and their unique stylistic and aesthetic effects, and this paper from a perspective of cognitive phonetics and cognitive psychology, finds that the church bells are the overtone of death, and the jingling sound as well as the tapping sound reveals one major theme of the novel: sexuality.
\end{abstract}

Index Terms —Ulysses, symbolic sounds, overtone of death, sexuality

\section{INTRODUCTION}

Ulysses takes us into the external and internal worlds of Leopold Bloom; we see through his eyes, hear through his ears and think through his thoughts. All through the book, all kinds of sounds impinge on our ears from all sides. They may be human or nonhuman, loud or low, soft or rough, funny or ridiculous, such as the callings of the cat, the chimings of the bells of George's church, the various sounds of the printing machines, of percussion instruments, of the hackney, of the audience's applause, of the clinking glasses, of the blind tuner's "tepping-tapping", and above all, of Bloom's unbecoming farting.

Sound here is used in its broad sense, referring to something that is or may be heard, or something that causes a sensation in the ear, or a quality of something that is read or heard. Usually we value too much our own speech sounds and too little those non-human sounds. We consider the latter as "muddling sounds", and tend to overlook them. But Joyce is quite a queer writer who has developed an overt preference for those minutiae or those "muddling" sounds in life. It seems that few Joycean scholars have attended to Joyce's manipulating of sounds and their unique stylistic and aesthetic effects. "Cognitive phonetics deals with the mental processes involved in encoding and decoding the final stages of the transformation of thought to sound. It involves what needs to be invoked when inputting an idealised phonological requirement with a view to outputting a sound wave which has to be decoded back to some copy as little degraded as necessary of the original thought." (Tatham, 1990, p. 209) And this paper, from a perspective of cognitive phonetics and cognitive psychology, will explore the different symbolic or metaphorical implications of two distinctive sounds: the church bells and the jingling sound.

\section{The ChuRCh Bells: AN Overtone of DeATH}

At the end of Episode 4 "Calypso", Bloom walks out and hears the bells of George's church:

A creak and a dark whirr in the air high up. The bells of George's church. They tolled the hour: loud dark iron.

Heigho! Heigho!

Heigho! Heigho!

Heigho! Heigho!

Quarter to. There again: the overtone following through the air, third.

Poor Dignam! (4: 85)

"Heigho!" is the bell sound to announce the time in the Westminster pattern: each phrase of four notes indicates a quarter hour, and at the end of the hour, after four phrases, a low bell tells the number of hours. But the church bells here are not only indicating the morning time 8: 45 a.m., but "throughout the day Bloom will associate this sound with his acquaintance Paddy Dignam, who has died, and with Dignam's funeral" and "the phrase that went through Stephen's mind at the end of 'Telemachus' ('Liliata rutilantium'), also associated with death"2. "Liliata rutilantium... chorus excipiat" (1: 11) appears twice in Episode 1, once in Episodes 9, 15 and 17 respectively. It is a Latin prayer for the dying and it goes: "May the glittering throng of confessors, bright as lilies, gather about you. May the glorious choir of

\footnotetext{
*Funded by 2015 China National Social Science Project “A Cognitive Poetics Approach to Ulysses", Project No: 15XWW002).

1 This refers to chapter and page numbers, 8: 11 means Chapter 8, Page 11 in Ulysses(James Joyce, 1996), and all the other examples follow the same format.

${ }^{2}$ http://www.robotwisdom.com/jaj/ulysses/notes04.html\#calypso. 2003.3.
} 
virgins receive you." (Gifford \& Seidman, 1988, p. 27) So the church bells are metaphorically used, predicting Bloom's gloomy day and symbolizing death, and moreover, I proceed to argue that the church bells function as an overtone of death and other images of death as echoing leitmotifs in the novel. "Overtone" here refers to "one of the higher tones produced simultaneously with the fundamental and that with the fundamental comprise a complex musical tone". (Merriam-Webster's Dictionary $\left.{ }^{3}, 2002\right)$

Episode 4 is a chapter to introduce Leopold Bloom, a key character in the novel. The scene is Bloom's house, 7 Eccles Street, in the northwest quadrant of Dublin. Bloom is preparing breakfast for himself and his wife (and the cat) before departing for Paddy Dignam's funeral. The jingling springs of the bed upstairs announce that his wife Molly is awake. He muses upon the source of the bed: it came, like Molly, from Gibraltar. He goes out to buy a pork kidney he likes very much. On the way, he daydreams on a range of themes, and fantasizes about women he sees, muses about the exotic Mediterranean. He hurries home, picking up mail on the doorsteps: one letter from his daughter Milly, another for his wife from Blazes Boylan, who is both the organizer of a concert tour which features Molly and, at present, her lover. Bloom scorches his kidney, then goes out to the outlet house, and then he hears the church bell.

Before the bell strikes, Joyce describes: "A creak and a dark whirr... high up", "tolled the hour", "loud dark iron". After the bell, there is the creaking lingering sound of "the overtone following through the air, third". All these words or phrases carry negative implications, suggesting a sort of dark, gloomy and horrible atmosphere. It is really an ill omen to Bloom at the early morning and it will naturally remind him of Poor Dignam's funeral in Episode 6. It predicts that Bloom will spend a blue day. As expected, Bloom has had the most miserable day: his wife's adultery with Boylan, his being despised and wronged by some radical nationalists, almost being hit on the head by the citizen in Episode 12, and so on. Despite all these humiliations and mishaps, to our great relief, Bloom never gives up, never loses confidence and finally reaches his home like Ulysses. Throughout the day, Bloom and other characters will associate this metaphorical sound with Dignam's funeral, and with death in particular. For examples:

Callan, Coleman, Dignam Patrick. Heigho! Heigho! Fawcett. Aha! Hust I was looking...(11: 360)

THE BRACELETS: Heigho! Heigho! (15: 678)

What echoes of that sound were by both and each heard?

By Stephen:

Liliata rutilantium. Turma circumdet.

Iubilantium te virginum. Chorus excipiat. 4

By Bloom:

Heigho, Heigho,

Heigho, Heigho. (17: 826-827)

The "Heigho, Heigho" sound turns up here and there in Episodes 11, 15 and 17 of the novel, functioning as one of the themes of the novel. There are other leitmotifs to reinforce the theme, for examples, the recurrent Latin phrase "Liliata rutilantium"- suggesting of death, and Paddy Dignam's name mentioned a dozen of times in the interior monologues, in the utterances of characters, and even in Molly's stream of consciousness "poor Paddy Dignam all the same" (18: 920). Stephen's cliché "Agenbite of Inwit" (1: 18) is also associated with his mother's death. This Middle English phrase means "remorse of conscience." "Agenbite of Inwit" (1340) is a medieval manual of virtues and vices, intended to remind the layman of the hierarchy of sins and the distinctions among them. (Gifford \& Seidman, 1988, p. 22) What's more, there are a lot of persons, things and objects related to the subject of death all through the novel. Please consider the following examples:

[Bloom] —O no, Mr Bloom said. Poor Dignam, you know. The funeral is today. (5: 89)

[M'Coy] —What's wrong with him? He said. He's dead, he said.... Is it Paddy Dignam? I said....Yes, he said. He's gone. He died on Monday, poor fellow. (5: 90)

[Bloom's monologue] A fellow could live on his lonesome all his life. Yes, he could. Still he'd have to get someone to sod him after he died though he could dig his own grave. We all so. Only man buries. No ants too. First thing strikes anybody. Bury the dead. (6: 138)

[Bloom's monologue] Poor papa with his hagadah book, reading back-wards with his finger to me. Pessach. (7: 155)

[Bloom's monologue] Brains on their sleeve like the statue in Glasnevin. (7: 159)

[Bloom's monologue] Those two loonies mooching about. Dignam carted off. Mina Purefoy swollen belly on a bed groaning to have a child tugged out of her. One born every second somewhere. Other dying every second. (8: 208)

[Stephen's monologue] Mother's deathbed. Candle. The sheeted mirror. Who brought me into this world lies there, bronelidded, under few cheap flowers. Liliata rutilantium. (9: 243) (the first italics mine, the second original)

[Stephen's monologue]... Who let Him bury, stood up, harrowed hell, fared into heaven ....but yet shall come in the latter day to doom the quick and dead when all the quick shall be dead already. (9: 253)

[John Conmee's monologue] What was that boy's name again? Dignam, yes. Vere dignum et justum est. ${ }^{5}$ (10: 280)

\footnotetext{
3 http://www.m-w.com/cgi-bin/dictionary?book=Dictionary\&va=overtone. 2004,11 .

4 Latin: "May the glittering throng of confessors, bright as lilies, gather about you. May the glorious choir of virgins receive you. May the glorious choir of virgins receive you". The Layman's Missal (Baltimore, Md., 1962) quotes this as one part of Prayers for the Dying and remarks, "In the absence of a priest, these prayers for commending a dying person to God, may be read by any responsible person, man or woman". (Gifford \& Seidman, 1988: 19)
} 
[Master Dignam's monologue] A big coffin it was, and high and heavylooking.... That was Dignam, my father. (10: 324)

[Bloom's monologue] Callan, Coleman, Dignam Patrick. Heigho! Heigho! Fawcett. Aha! Just I was looking... (11: 360)

[Bloom's monologue] Waken the dead. Pom. Dignam. Poor little nominedomine ${ }^{6}$. Pom. (11: 374) (the first two italics mine, the second original)

[Joe] -Don't you know he's dead? Says Joe. (11: 388)

[Alf] - Paddy Dignam dead? Says Alf. (11: 388)

[off-scene narrator] He is gone from mortal haunts: O'Dignam, sun of our morning. (11: 390)

These italicized words and phrases are explicitly or implicitly related to the deceased Dignam or death. The death theme is actually pervasive in the whole novel, let alone the numerous allusions to dead figures. Related examples in Episodes 1-3, though not listed here, are also involved in the matter of death in a way, for example, the drowning case in the first episode. If we say all these images of death function as leitmotifs, then the "Heigho" sound is the overtone higher than the fundamental. What's more, Episode 6 "Hades" is a special chapter about the subject of death.

At nearly 11 a.m., Bloom enters a funereal carriage with other friends to attend Paddy Dignam's funeral, and there four people in the carriage: Jack Power, Martin Cunningham, Simon Dedalus (Stephen's father) and Bloom. Joyce called the technique of Episode 6 "incubism". An incubus is an evil spirit who causes nightmares and worse by lying on top of the sleeper, so one supposes the writing is intended to produce a nightmarish effect by heavy repetition and emphasis on death. It is certainly successful in this: not only is every aspect of death and decay discussed gruesomely and vividly, but there are many oblique or hidden references to death, especially to the failure of the heart, which is the organ of the episode. "The chapter might be centered on the traditional rhyme of womb and tomb. 'In the midst of life we are in death', as 'The Burial of the Dead' in the Prayer Book puts it; but here in the midst of death there is lots of life." (Hodgart, 1983, p. 86) So for Joyce, there is a dialectical relationship between life and death, that is, "in the midst of death there is lots of life."

Piled on the images of death over the novel is the distinctive overtone of death which "with the fundamental comprise a complex musical tone" of death. The "Heigho" sound plays a dark or gloomy keynote for the whole novel. Such an overtone of death lends itself to presenting before us an actual Dublin at the turn of the $20^{\text {th }}$ century, which "seems to contain no healthy institution, to permit no satisfying way of life" and which "has an aura of despair, poverty, drunkness, and waste". (French, 1982, p. 30) The keynote of death provides a good answer to the question why the church circle could not stand Joyce and his Ulysses 80 years ago. At the end of A Portrait, Stephen (Joyce's mouthpiece) told his friend Cranly: "When the soul of a man is born in this country there are nets flung at it to hold it back from flight. You talk to me of nationality, language, religion. I shall try to fly by those nets.... Ireland is the old sow that eats her farrow." (Joyce, 1996(a), p. 184-185) Later, he said, "I will not serve that in which I no longer believe whether it calls itself my home, my fatherland or my church". (Joyce, 1996(a), p. 222) Joyce's biting sarcasm and fierce attacks on Dublin's society and the Catholic church find full expression in the above-quoted words and the church bells in particular.

\section{THE "Jingling” SOUNDS: SugGeSting SeXuality}

Episode 11 "Sirens" is set at 4 p.m. and the scene is the Concert Room - the saloon at the bar and restaurant of the Ormond Hotel. The Ormond bar was a favorite haunt of Dublin's amateur musicians, and the saloon was frequently the setting for the small concerts that were popular at the turn of the century and in which the distinction between amateur and professional was not of much importance. This episode is known as a chapter of songs and musical allusions, but I will leave them for the time being. Besides songs and musical allusions, the episode, in fact, is rife with sounds: the singing and the playing of piano, the recurrent tapping sound of the piano-tuner's cane. There are other sounds as well: hoofs ringing, coins clanging, clocks whirring and clacking, garters smacking, the bar patrons applauding "Clapclipclip clap" and "Clapclopclap" and crying, among their bravos, "Sound as a bell", and so on. Blazes Boylan is represented throughout by his "Jingle. Jingle." When characters grunt, snuffle, shriek, huff, snort, sniff, sigh, ruffle, splutter, cough and "plapper flatly", Bloom even makes a loud farting sound "Pprrpffrrppff"! "Sirens," appropriately enough, is an episode that asks to be approached first and foremost through the listening ear. Of all those sounds, the "jingling" sound of the hackney is particularly distinctive, suggesting another theme of the novel: sexuality.

The jingling sound almost reverberates in the ear while reading Ulysses. I have entered three key words "jingle", "jingled" and "jingling" into Concordance Text Search" and have obtained the following results:

jingle (total: 7)

$132.45^{8}$ prints, silkdames and dowagers, jingle of harnesses, hoofthuds lowringing (8: 213)

203.29 Jingle jingle jaunted jingling. (11: 329)

\footnotetext{
${ }^{5}$ Latin: "It is indeed fitting and right"; the opening phrase of the preface, which begins the Eucharist (the canon or central section of the Mass). (Gifford \& Seidman, 1988: 260)

${ }^{6}$ Latin: "in the name of God" (ibid: 294)

7 http://www.grand-teton.com/cgi-bin/jjoyce/omnisearch.cgi? 2004, 11.

8 The page numbers on the left are the results of the retrieval, those on the right mine.
} 
208.68 Jingle jaunty jingle. (11:337)

216.22 Jiggedy jingle jaunty jaunty. (11: 349)

223.2 Great Brunswick street, hatter. Eh? This is the jingle that joggled and (11:361)

358.30 negroid hands jingle the twingtwang wires. Flashing white kaffir (15: 573)

379.19 The brass quoits of a bed are heard to jingle. (15: 595)

jingling (total: 7)

48.89 She set the brasses jingling as she raised herself briskly, an elbow on (4:76)

102.32 jingling his keys in his back pocket. They jingled then in the air and against (7: 165)

203.29 Jingle jingle jaunted jingling. (11: 329)

377.33 (stamps her jingling spurs in a sudden paroxysm of fury) (15: 593)

474.17 has cleared off From the left arrives a jingling hackney car. It slows (15: 685)

492.27 that he is reassuraloomtay. The tinkling hoofs and jingling harness (15: 701)

626.16 bed too jingling like the dickens I suppose they could hear us away over (18: 914)

jingled (total: 5 )

43.47 softer, as she turned over and the loose brass quoits of the bedstead jingled. (4: 67)

102.32 jingling his keys in his back pocket. They jingled then in the air and against (7: 165)

215.2 By Bachelor's walk jogjaunty jingled Blazes Boylan, bachelor, in sun (11:347)

223.4 jingled. By Dlugacz' porkshop bright tubes of Agendath trotted a (11: 361)

515.15 scooped anyway for new foothold after sleep and harness jingled. Slightly (16: 739)

Among these 19 examples, there are three repetitions: "Jingle jingle jaunted jingling" (11: 329), "jingling his keys in his back pocket..." (7: 165) and "jingled. By Dlugacz' porkshop." (11:347) By the way, the search results are by no means conclusive and it seems that the internet is also confused by so many "jingling" sounds in the book. For example, just in "Sirens" episode, there are 15 more "jingling" sounds (not including repetitions):

Jingle.

-With the greatest alacrity, Miss Douce agreed. (11:336)

With patience Lenehan waited for Boylan with impatience, for jingle jaunty blazes boy. (11: 339)

Jingling on supple rubbers it jaunted from the bridge to Ormond quay. (11:339)

Jingle haunted by the curb and stopped. (11:340)

Jingle a tinkle jaunted. (11: 345$)$

Bloom heard a jing, a little sound. He's off. Light sob of breath Bloom sighed on the silent bluehued flower. Jingling. He's gone. Jingle. Hear. (11: 345)

Jingle haunted down the quays. Blazes sprawled on bounding tyres. (11:346)

jingledy jiggedy (11:349)

By Graham Lemon's pineapple rocks, by every's elephant jingle jogged. (11: 350)

Touch water. Jingle jaunty. (11: 351)

Jingle all delighted. He can't sing for tall hats. (11:353)

Jingle by monuments of sir John Gray, Horatio onehandled Nelson, reverend father Theobald Matthew, jaunted as said before just now. (11: 356$)$

Write me a long. Do you despise? Jingle, have you the? (11: 360)

This is the jingle that joggled and jingled. (11:361)

Jog jig jogged stopped. Dandy tan shoe of dandy Boylan socks skyblue clocks came light to earth. (11: 364)

A "jingle" is a two-wheeled horsedrawn carriage and "jaunted" refers to making a short pleasure journey. A "jingle" easily reminds us of the happy song "Jingle Bells" by John Pierpont (1785-1866), particularly the phrases "Laughing all the way" in the first verse and "Take the girls tonight" in the third and the chorus: "Jingle bells! Jingle bells! / Jingle all the way!" What a nice jingling! But what does Joyce imply in this context? To answer the question, we need to examine the "jingling" sounds all over the book. The "jingling" motif starts from the jingling bed frame (4: 67, 76), goes through Episodes 7, 11, 15 and 17, and ends with Molly's stream of conscious (18: 914, 917). Episode 11 is a chorus of jinglings and they appear over 30 times. From Molly' three more pieces of monologue, we may know more about the jingling bed:

No. She did not want anything. He heard then a warm heavy sigh, softer, as she turned over and the loose brass quoits of the bedstead jingled. Must get those settled really. Pity. All the way from Gibraltar. Forgotten any little Spanish she knew. Wonder what her father gave for it. Old style. Ah yes, of course. Bought it at the governor's auction. Got a short knock. Hard as nails at a bargain, old Tweedy. Yes, sir. At Plevna that was. I rose from the ranks, sir, and I'm proud of it. Still he had brains enough to make that corner in stamps. Now that was farseeing. (4: 67)

... this damned old bed too jingling like the dickens I suppose they could hear us away over the other side of the park till I suggested to put the quilt on the floor with the pillow under my bottom I wonder is it nicer in the day I think it is easy I think Ill cut all this hair off me.... (18: 914)

now the lumpy old jingly bed always reminds me old Cohen I suppose.... (18: 917)

It turns out that the jingling brass bed comes a good way from Gibraltar where Molly spent her innocent girlhood and where her father bought the "old style" bed at a cheap price at the governor's auction and sent it as a wedding gift to the 
young couple 16 years ago. What annoys them is that the bed is always betraying their sensual joys by making incessant obstinate jingling noises, so Molly is worried about that "they could hear us away over the other side of the park" and she comes up with a good idea "to put the quilt on the floor with the pillow under my bottom". It is natural that both Bloom and Molly are accustomed and sensitive to the jingling sound, which is likely to be an amusing secret code about their bed affairs. So the "jingling" sound is a symbol of sex understood tacitly by Bloom and Molly, and even by Boylan. Then, why are there so many jingling sounds in Episode 11?

The "Siren" episode takes place at 4 p.m., the exact time that Molly and Boylan will have their tryst. But for Bloom, and it is certainly the worst time of the day. What's more, Bloom cannot escape hearing about Molly's upcoming tour with Boylan. Now the poor dog chooses to "eat" his sorrows down at the bar overhearing the Concert Room. The bar is boiling with clicking cups and flirtatious giggles and loud musical notes. Bloom is busy himself with food: "Leopold cut liverslices. As said before he ate with relish the inner organs, nutty gizzards, fried cod's roes while Richie Goulding, Collis, Ward ate steak and kidney, steak then kidney, bite by bite of pie he ate Bloom ate they ate." (11: 347) All the time, his head goes wild with the jingling sounds, with Boylan's "bounding tyres" and jingling bell, with Molly, above all with sex. On the contrary, Boylan is beaming with pride and complacence on his face. At the end of Episode 10, we see him first buying flowers at the flower store, then coming "jauntily Blazes Boylan, stepping in tan shoes and socks" in a hackney (10: 327), humming "My Girl's a Yorkshire Girl”, then having a short stay at the bar, and jingling proudly away.

The "jingling bed" motif-sexuality, is one of the themes of the novel. It is developed midway through Ulysses, foreshadowing the treatment of the marriage bed in "Penelope". In the previous episode "Scylla and Charybdis", Stephen's Shakespearean criticism also deals with the motif by expounding upon Ann Hathaway's infidelity and the "secondbest bed" bequeathed to her by her playwright husband. The "jingle jingle" of the loose (and unfaithful) bed of Penelope/Molly becomes the "jaunted jingling" of the wandering Ulysses/Bloom's absent "jingling" key. "Jingle jingle" mirrors the alliteration of Blazes Boylan's name and parodies his cocky swagger into the Ormond. By the way, "blazes" is a euphemism for "Hell" or "the Devil". "Go to blue blazes" means "Go to Hell!"

Some traditional critics condemn Molly as a dirty lascivious woman and as a negative example quite different from the original Penelope in The Odyssey whose marital devotion is unmatched; others argue that Molly is a new manly woman who is brave enough to challenge the die-hard old ideas about sexuality. For long, Joyce's sexuality has been one of the heated topics and it calls for further studies.

A "tap" sound starts where the jingling ends. The rhythmic sound rings 15 times in the last 7 pages of the "Siren" episode. It gradually gains in frequency from one "tap", two "taps"... to 8 "taps" at its climax. (11: 373) This sound originally comes from the tapping cane of the blind piano-tuner of the Ormond bar. "Tap blind walked tapping by the tap the curbstone tapping, tap tap." (11: 372) Bloom's ears are stuffed throughout the episode with the "Tap" sound. Naturally, Bloom will associate it with sounds in the bar. Miss Douce's response to Simon Dedalus' inquiry about her holidays is "Tiptop"; the waiter's name, "Pat," is "tap" reversed.

Ridiculously Bloom even imagines Boylan's intercourse with Molly as "Tipping her tepping her tapping her topping her". (11: 354) According to Gifford and Seidman (1988, p. 303), all of these $t$ - $p$ "verbs" have in common the archaic meaning: to copulate as animals. To "tup" and to "tip" mean "to copulate as a ram does". To "top" means to cover as an animal covers, and both "tap" and "tep" are dialect variants of "top". "Tipping" is also a musical term for double-tonguing. It is not surprising that sex is on Bloom's mind; he is trying desperately not to think about his wife's tryst with Blazes Boylan, which he knows is taking place during this episode, but he fails. Erotic overtones are not limited to Bloom's thoughts, however; they pervade all of the language of "Sirens". This complex web of rhythmic sound correspondences creates a kind of "invading flow" of accumulated meanings, so that the repeated "tap" of the piano-tuner's cane, for example, evokes Boylan's intercourse with Molly, as well as Boylan's knock on the door of 7 Eccles Street - “One rapped on a door, one tapped with a knock, did he knock Paul de Kock with a loud proud knocker with a cock carracarracarra cock." (11:364).

Besides those distinctive sounds, everything speaks in its own way: the sound of glasses in the Ormond bar ("Tschink. Tschink", 11: 330); Bloom's body noises (e.g. "Pprrpffrrppfff", 11: 376), the clapping sound ("Clapclop. Clipclap. Clappyclap." 11: 330), Bloom's imagined sound of Molly's water (Diddleiddle addleaddle ooddleoodle. Hissss." 11: 364); the noise of the printing presses in "Aeolus ("Sllt", 7: 154); numerous objects in "Circe" which have their own speaking parts: cooing kisses and wailing gaaets ("Pfuiiiiiii") and the train whistle in Molly's monologue in the last episode ("Frseeeeeeefronning train", 18: 894). Indeed, Ulysses creates a world of sounds.

\section{SUMMARY}

Generally, these "muddling" sounds in Ulysses are playful, musical, emotional and expressive. But it seems that few Joycean scholars have attended to Joyce's manipulating of sounds and their unique stylistic and aesthetic effects, and this paper, from a perspective of cognitive phonetics and cognitive psychology, finds that a few foregrounded sounds carry some rich symbolic or metaphorical implications, i.e. the church bells suggesting the overtone of death, and the jingling sound as well as the tapping sound implying one major theme of the novel: sexuality. "Joyce's abandonment of the church consisted in a shift of ideas that both he and his brother described as a shift from belief in a God to a belief in the sexual instincts that make up the human spirit.... Wherever Joyce's reading took him (to Blake and Defoe; to the 
mystical fictions of W. B. Yeats; to his earliest and strongest authority, Ibsen; to the Bible, Aquinas and esoteric theology; or to Shakespeare and Homer in whom he invested the full imaginative energy of his mature years) he found a confirmation of his interest in sexuality and he shows his own preoccupation with each author's treatment of sex." (Brown, 1990, p. 126) The theme of sex permeates not only in "Sirens" but also other episodes of the novel.

\section{REFERENCES}

[1] Brown, R. (1990). James Joyce and Sexuality. Cambridge: Cambridge University Press.

[2] French, M. (1982). The Book as World. London: Sphere Books Ltd.

[3] Gifford, D. \& R. J. Seidman. (1988). Ulysses Annotated. Berkeley: University of California Press.

[4] Hodgart, M. (1983). James Joyce. London: Routledge \& Kegan Paul.

[5] Joyce, James. (1996). Ulysses. Nanjing: Yilin Press.

[6] Joyce, J. (1996a). A Portrait of the Artist as a Young Man. Nanjing: Yilin Press.

[7] Joyce, J. (1996). Ulysses. Nanjing: Yilin Press.

[8] Tatham, M. (1990). Cognitive Phonetics. In Ainsworth, W.A. (ed.) Advances in Speech, Hearing and Language Processing, Vol. 1. London: JAI Press.

Xianyou Wu is currently a professor of English at School of Foreign Languages and Literatures, Chongqing Normal University, China, and also Head of the School. He earned his Ph. D in English Language and Literature from Henan University in 2005, China. As a visiting scholar, he made his research at Shefield University, UK, from Sept, 2009 to August, 2010. His research interests cover literary stylistics, cognitive poetics and Joyce studies. He is responsible for some 10 research programs, including 2015 China National Social Science Project, and has published 5 books and some 60 articles in Chinese or oversea academic journals, including Journal of Language Teaching and Research and Theory and Practice in Language Studies.

Yi Zheng is an associate professor and MA supervisor at School of Foreign Languages and Literatures, Chongqing Normal University. He got his MA degree from Chongqing Normal University and his research interests cover literary studies and cognitive stylistics. He has published over 20 papers in Chinese academic journals. 